\title{
UNIVERSITYOF
}

FORWARD

THINKING

WESTMINSTER用

WestminsterResearch

http://www.westminster.ac.uk/westminsterresearch

\section{Airportscape and its Effect on Airport Sense of Place and Destination Image Perception}

Wattanacharoensil, W., Fakfare, P. and Graham, A.

This article is ( ) Emerald and permission has been granted for this version to appear here: http://westminsterresearch.westminster.ac.uk/

Emerald does not grant permission for this article to be further copied/distributed or hosted elsewhere without the express permission from Emerald Group Publishing Limited.

The final, published version in Tourism Review, DOI: 10.1108/TR-01-2021-0036, 2021 is available at:

https://doi.org/10.1108/TR-01-2021-0036

This manuscript version is made available under the CC-BY-NC-ND 4.0 licence https://creativecommons.org/licenses/by-nc-nd/4.0/

The WestminsterResearch online digital archive at the University of Westminster aims to make the research output of the University available to a wider audience. Copyright and Moral Rights remain with the authors and/or copyright owners. 


\title{
Airportscape and its Effect on Airport Sense of Place and Destination Image Perception
}

\begin{abstract}
Purpose - This study aims to validate a conceptual definition of airportscape and develop a multidimensional scale that integrates servicescape and service quality dimensions in order to comprehensively investigate airport service management. In addition, the study examines the structural relationships amongst airportscape, sense of place, airport image and destination image.

Design/methodology/approach - Covariance-based structural equation modelling has been employed. This study has collected the responses from 1,189 Thai respondents who had their experience in an international airport in the past 12 months.

Findings - Key findings reveal the set of three airportscape attributes which positively influenced the air traveller's perceived sense of place. Four other dimensions were found to positively influence the airport image. The results also suggested the positive relationships amongst sense of place, airport image and destination image. Sense of place strongly predicted the destination image and airport image, and was found to be an important mediator of the relationship between airportscape dimension and perceived image variables

Originality/value - The study validates the airportscape scale and introduces "sense of place", a concept that has not been objectively investigated in the airport context, and in relation to tourism. The findings provide insights to airport managers and tourism authorities by examining areas that highlight an airport's sense of place and representation of the destination. The study also strengthens the theoretical link between airport and tourism knowledge, by showing that the airport's sense of place can strongly influence airport image and destination image. The result ascertains that the airport can be a representative of a destination through the creation of a sense of place.
\end{abstract}

Keywords: Airportscape; Airport Image; Destination Image; Sense of Place;

Paper type Research paper 


\section{El paisaje del aeropuerto y su efecto en la percepción de la imagen y el destino del aeropuerto}

\section{Resumen}

Propósito - Este estudio tiene como objetivo validar una definición conceptual del paisaje aeroportuario y desarrollar una escala multidimensional que integre el paisaje de servicios y las dimensiones de la calidad del servicio con el fin de aportar exhaustividad a la investigación de gestión de servicios del aeropuerto. Además, el estudio examina las relaciones estructurales entre el paisaje aeroportuario, la percepción del lugar, la imagen del aeropuerto y la imagen del destino.

Diseño / metodología / enfoque - Se ha empleado el modelado de ecuaciones estructurales basado en covarianza. Este estudio ha recopilado las respuestas de 1.189 encuestados tailandeses que tuvieron su experiencia en un aeropuerto internacional en los últimos 12 meses.

Conclusiones - Los hallazgos clave revelan el conjunto de tres atributos del paisaje del aeropuerto que influyeron positivamente en la percepción del sentido de lugar del viajero aéreo. Se encontró que otras cuatro dimensiones influyen positivamente en la imagen del aeropuerto. Los resultados también sugirieron las relaciones positivas entre el sentido de lugar, la imagen del aeropuerto y la imagen del destino. El sentido del lugar predijo fuertemente la imagen del destino y la imagen del aeropuerto, y se encontró que era un mediador importante de la relación entre la dimensión del paisaje del aeropuerto y las variables de la imagen percibida.

Originalidad / valor - El estudio valida la escala del paisaje del aeropuerto e introduce la "percepción del lugar", concepto que no ha sido investigado objetivamente en el contexto aeroportuario y en relación con el turismo. Los resultados proporcionan información a los gestores de los aeropuertos y a las autoridades turísticas al elaborar elementos y áreas que destacan el sentido del lugar del aeropuerto y representan el destino. El estudio también refuerza el vínculo teórico entre el conocimiento del aeropuerto y el turismo, al mostrar que el sentido del lugar del aeropuerto puede influir fuertemente en la imagen de este y en la imagen del destino. El resultado demuestra que el aeropuerto puede ser representativo de un destino a través de la creación de un paisaje.

Palabras clave: Paisaje aeroportuario; Imagen del aeropuerto; Imagen de destino; Percepción;

Tipo de documento Documento de Investigación. 


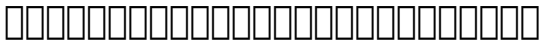

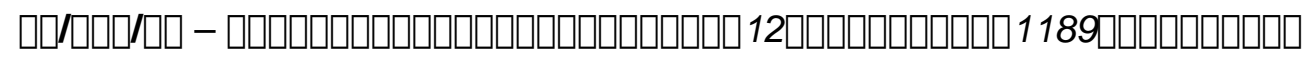

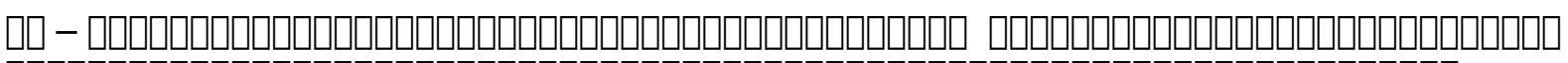

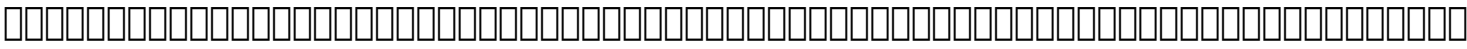

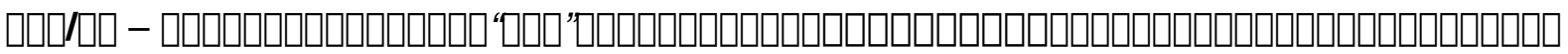

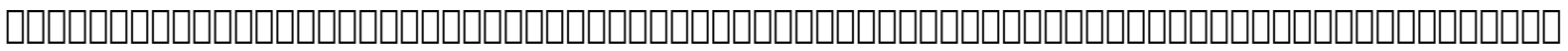

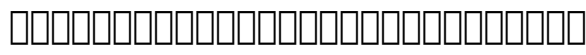

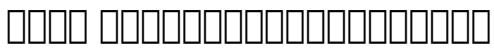

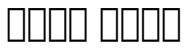

\section{Introduction}

Within the service management discipline, service quality and the service environment have major influences on the psychological and emotional evaluations of consumers towards businesses. After the seminal research of service quality by Parasuraman et al. (1985) and the servicescape by Bitner (1992), numerous studies have investigated various arrays of service dimensions, and ways for organisations to create favourable service performance. This is to enhance potential benefits derived from achieving improved operational outcomes and for increasing customer satisfaction (Fu et al., 2020). This is specifically the case for the airport industry. 
The competitive environment, encouraged by airline liberalisation, airport privatisation and a significantly increased role of commercial activities, has made airports adopt a business model approach to ensure healthy financial returns derived from the non-aeronautical revenues, and to place air travellers amongst key revenue sources (Duval, 2020; Graham, 2019; Sarlay and Neuhofer, 2020). Airports use key industry measures, from the Airport Council International (ACl)'s airport service quality (ASQ) surveys and other sources, to help them improve their operations and enhance customer satisfaction (Bezerra and Gomes, 2013; Prentice and Kadan, 2019).

The demand for experiential consumption (Holbrook and Hirschman, 1982) has also been increasing in recent decades. Thus, additional concepts, such as the servicescape, have been considered within the airport context, which highlight the features of airport physical/terminal design (Park and Ryu, 2019). The reason is that research has found that physical/environmental stimuli have powerful impacts on eliciting positive customer emotion and satisfaction (Hyun and Kang, 2014; Jen et al., 2013; Moon et al., 2016). As a consequence, numerous airports have allocated resources to improve their layout and facilities to ensure a positive airport experience for passengers.

However, most previous research regarding airports has examined the singular influence of either the airport servicescape or airport service quality on tested variable outcomes (e.g., satisfaction and intention behaviour); as far as we are aware, no studies have integrated the dimensions of the servicescape and airport service quality together and constructed measurement dimensions that include comprehensive key airport functions and facilities. It is especially in the airport terminal, both in the landside and the airside areas (e.g., check-in, security, immigration and gate/boarding areas), where passengers predominantly spend most time, perceive airport service performance and develop their airport experience. Thus, a construct that has a multidimensional nature and reflects the servicescape and service quality dimensions needs to be developed to fulfil this paucity. Accordingly, this study proposes the term 'airportscape' as an operational definition that refers to the airport multidimensional construct, which is determined by the key service functions and facilities of the airport's terminal as main attributes. The construct incorporates servicescape and service quality dimensions to create a comprehensive assessment of airport service performance identified by these attributes.

Moreover, apart from the role of the servicescape and service quality, an increasing number of airports have been emphasising the concept of a sense of place in the terminal interior and design to enhance the experiential and emotional connection of air travellers and the airport (Holland, 2017; Kaduoka, 2019; Masjutina, 2017) and, as a consequence, to the destination (Wattanacharoensil et al., 2016). By definition, a sense of place, which is developed from the seminal concept of place and placelessness (Relph, 1976), refers to the elements of the physical environment, human behaviour and social and/or psychological processes interwoven together to create the place's meaning and attachment (Stedman, 2003). The concept of a sense of place has been mentioned in the study of Rosenbaum and Massiah (2011), who expanded Bitner's servicescape framework and suggested that place studies should be included in the general servicescape dimensions. Creating a sense of place in the airport terminal benefits a destination by allowing the airport to introduce the destination identity, which can psychologically stimulate air travellers to connect the destination to the airport. 
Evidence in practice is observed in various airports where cultural artefacts and activities are introduced to air travellers inside the airport terminal to impart a sense of destination once passengers arrive and depart from the airport. For instance, Incheon Airport (ICN - using airport code by International Air Transport Association (IATA)) has Korean Traditional Culture Experience Centres in their concourses in both Terminal 1 (T1) and Terminal 2 (T2) to showcase the Korean cultures through activities and exhibitions (Incheon International Airport Corporation, 2020). Another example is Tokyo Haneda Airport (HND) with its Edo marketplace, which features the traditional Japanese market from the Edo period (1603-1868) in the airport terminal (Ministry of Foreign Affairs of Japan, 2020). However, to date, very few studies in the airport context have investigated the role of the sense of place and its relationship to airport and destination images. The present research is conducted to also fill this gap.

Therefore, this study has the following two aims:

- To develop a conceptual definition for the dimensions of airportscape and to conduct a scale validation that measures its various dimensions;

- To examine the structural relationships amongst airportscape dimensions with sense of place and airport image, and to investigate the influence on the image of a destination.

In summary, this study provides a theoretical foundation by adding insights, particularly in terms of the airportscape, airport's sense of place and image perceptions into the airport literature. By developing and validating the multidimensional airportscape measurements, this work is expected to provide a comprehensive airportscape scale for future researchers to employ in airport studies. Drawing on a structural equation modelling approach, this study ascertains that the airport can be a representative of a destination through the creation of a sense of place, thereby strengthening the theoretical connection between airport and tourism studies. In addition to the theoretical implications, the findings offer practical insights for airport authorities, Destination Management Organisations (DMO) and service providers to ensure the quality of the airport services and to highlight the areas where the airport can represent the image of the destination within its terminal buildings.

The rest of the paper is divided into the following sections: the literature review, which describes the key concepts required for the study with the proposed hypotheses; the methodology; the findings; the discussion; the conclusions; and the implications.

\section{Literature review}

\section{Servicescape and airport service quality}

Servicescape, an environment constituted by service firms, represents a manmade or physical environment that has certain impacts on multi-facets of customer experiences (Bitner, 1992; Chang, 2016). Since this is an artificial consumption environment, servicescape has a critical role in creating first impressions and shaping customer attitudes towards service provision of the firms (Park and Park, 2018). Although servicescape has been examined in different areas of hospitality and tourism, the identified servicescape dimensions are diverse. Since a physical experience is created where services are rendered, a customer's value perception, 
satisfaction and behavioural response to servicescape factors varies across different industries (Chang, 2016). For example in leisure research, Dong and Siu, (2013) divided the servicescape into two major categories: the physical creations of the service environment and communication. In the hotel context, Li (2021) proposed that the servicescape comprised hotel architecture, atmosphere, facilities, décor, smell and employee communication dimensions. In tourist destination research, Oviedo-García et al. (2019) included services, facilities, and information in the servicescape model to verify their predictive power to tourist satisfaction, value perception and behavioural intentions.

In the airport context, recent research has investigated the servicescape with various variable outcomes to apply this concept to the airport terminal. Bogicevic et al. (2016) examined the effect of the physical environment in the airport terminal on the emotional response of passengers, especially enjoyment and anxiety. The results revealed six important specific attributes (i.e., design, scent, functional organisation, air/lighting conditions, seating and cleanliness) in the airport servicescape. Moreover, design and scent are the strongest predictors of travellers' enjoyment, and poor functional organisation and inadequate air and lighting conditions are major predictors of travellers' anxiety. Moon et al. (2016) investigated the influence of the airport physical environment on passenger satisfaction by using two emotional stages (pleasure and arousal) as moderating factors. The findings revealed the importance of layout, facility aesthetics and cleanliness on customers' pleasure, which leads to their satisfaction. Jeon and Kim (2012) assessed the effect of various dimensions of the servicescape in the airport on customers' emotion and behavioural intention. The results showed that the functional factor, aesthetic factor, safety factor, and social factor influence customers' positive emotions, whereas the ambient factor and social factor affect customers' negative emotions, and only positive emotions have an impact on behavioural intention. Park and Ryu (2019) extended the servicescape concept from the physical environment to the social environment and tested the effect of both aspects on traveller behavioural intention by using 'gender' as a moderator. The results showed that only physical servicescape has a significant impact on cognitive and affective satisfaction, and there is a gender difference between the physical servicescape and cognitive satisfaction, meaning that the male group accepted the service environment and service quality of the airport more rationally than the female group.

In the meantime, service quality research has always been abundant in the airport context, and most research has used context-based data for analysis. Apart from adapting the dimensions of SERVQUAL suggested by Parasuraman et al. (1985) into the airport context or airport specific dimensions proposed by Fodness and Murray (2007), the 34-attribute ASQ$\mathrm{ACl}$ is often used for the service quality measures and investigated in airport research. Studies have chosen the singular dimensions, ASQ attributes, or a combination of both to investigate service quality from various service performance perspectives, such as importanceperformance analysis (Tsai et al., 2011), its influence on passenger satisfaction (Bezerra and Gomes, 2016; Bogicevic et al., 2013) or its influence on destination choice (Prentice and Kadan, 2019). Recently, Trischler and Lohmann (2018) specifically assessed the data collected by the Australian Competition and Consumer Commission to provide in-depth analysis of the service quality methodology. Given factors that constitute ASQ and airport servicescape are diverse depending on the specific research, this current study attempts to integrate attributes of $A S Q$, airport service quality and airport servicescape, and establish a comprehensive multidimensional airportscape construct. The foregoing theoretical insights of 
the airport literature suggested the following potential dimensions: airport information/signage/layout, terminal ambience, flight information screens, check-in, security, basic facilities, immigration, gate area, baggage, and leisure/ entertainment (Bezerra and Gomes, 2016; Brida et al. 2016; Prentice and Kadan, 2019; Trischler and Lohmann, 2018). To achieve the research aim, this study uses the newly developed airportscape dimensions to assess the validity and accuracy of construct prediction in a proposed research model (Figure 1). So the current research provides the theoretical context by extending knowledge, particularly in terms of the airportscape in the airport literature.

\section{Airport and sense of place}

In recent years, airports have been significantly transformed from a mere location (NghiêmPhú and Suter, 2018) with a high level of sameness and repetitively utilitarian functions (Rowley and Slack, 1999) into a place where cultural experiences and futuristic designs (Figueiredo and Castro, 2019) are incorporated into the airport terminal environment. According to Figueiredo and Castro (2019), the architectural designs can reflect local culture, customs, histories and landscapes of the place, which can particularly portray the sense of place of a destination to passengers.

The sense of place concept was introduced within an airport context to alter the perspective from a non-place (Auge, 1995) to a place, where a meaning can be added (Lloyd, 2003). Shamai (1991) addressed sense of place as an umbrella concept of attachment to place, national identity and regional awareness. The definition of 'sense of place' was given by Stedman (2003), who classified the term into three elements: (1) physical environment, (2) human behaviour and (3) social and/or psychological processes. In relation to airports, Wattanacharoensil et al. (2016) argued that the physical environment is more often used to enhance the place identity, whereas the last two forms of human behaviour and social and/or psychological processes are less observed. The recent study by Figueiredo and Castro (2019) also suggested the airport can promote sense of place through architectural design, artwork, and local service staff. The creation of sense of place can be created as well by filling the airport's concessional spaces with local or regional brands to promote the local identity. Sense of place is often now discussed in the industry literature as it is a competitive element that gives the airport a distinct and/or cultural identity (Kaduoka, 2019; Masjutina, 2017), and as a consequence helps create airport branding identity (Masjutina, 2017). Currently, cultural activities and artefacts are still common forms used by airports to create a sense of place. For instance, apart from ICN and HND airports mentioned earlier, Zurich airport in Switzerland presents cow noises, yodelling and an animated Heidi to give air travellers a flavour of Switzerland (Kaduoka, 2019).

At present, travellers broadly seek a different, unique, local and authentic experience within the airport environment. Indeed, over $60 \%$ of international travellers in a survey ranked sense of place as an important part of their overall airport experience (Holland, 2017). Consistent with the aforementioned literature, this study hypothesises that passengers who experience a positive airport servicescape are likely to acquire a favourable sense of place of a destination. Thus, the first hypothesis is proposed as below:

H1: The confirmed underlying dimensions of the airportscape affect the sense of place positively. 


\section{Airport image}

The airport image is regarded as the holistic perception of an individual user of an airport (Nghiem-Phu and Suter, 2018) and can serve as an attribute indicator that influences airport satisfaction and consequent behaviour (Bogicevic et al., 2016). The airport image has become an important facet for airport branding. Similar to the country or place image, the airport image comprises two dimensions, namely, affective and cognitive images (Elliot et al., 2011). Affective image involves feelings (e.g., boredom, enjoyment and anxiety) that airport users feel when experiencing the airport, whilst cognitive image involves the perception of airport's physical attributes (e.g., servicescape, airport facilities, airportapps) and psychological attributes (e.g., courtesy, security, efficiency) of the airport environment (Baker, 1986; FloridoBenítez, 2016; Nghiem-Phu and Suter, 2018).

Although individual perception can be influenced by many factors such as gender, nationality, experience and type of service, an individual's perceived image of a place can influence the perception of a person towards the brand. In the current airport context, many airports have started to alter their image and want to be recognised as entities moving away from just providing the infrastructure that enables connectivity, to the place that creates an emotional connection in the minds of travellers (MacKenzie, 2019). Ariffin and Yahaya (2013) found the importance of incorporating national identity into the airport image, which leads to passenger enjoyment. Meanwhile, Nghiem-Phu and Suter (2018) found that passengers' affective image of the airport is attached to the host or nearby city. Moreover, Masjutina (2017) and McKenzie (2019) suggested that a sense of place helps create an identity and positive image of the airport. Accordingly, this study investigates the influence of servicescape and sense of place on airport image and posits the following hypotheses:

H2: The confirmed underlying dimensions of the airportscape affect the airport image positively.

H3: Passenger perception of the airport's sense of place affects the airport's image positively.

\section{Airport and destination images}

In destination research, image is a complex amalgam of tourist activities, destination products and attributes that contributes to the tourist's overall impression (Whang et al. 2016). Travellers generally gain impressions about tourist destinations through a selection process based on their past experiences and perceived information about the destination (Fakfare and Lee, 2019). According to Wattanacharoensil et al. (2017), the airport is a place where travellers form mental perception of characteristics of a destination. Park and Park (2018) also affirm that the airport servicescape and airport service quality are vital elements influencing the change in image formation and destination choices of travellers. Therefore, airports with modern facilities, well-equipped technology, and functional services and operations can possibly fulfil the traveller's desires and expectation, and foster favourable images of a destination where the airport is located (Florido-Benítez, 2016; Wattanacharoensil et al., 2017).

Previous studies have explored the relationship of an airport to a destination and so this research also tests the effect of airport image on destination image. Kirk et al. (2014) revealed 
that a negative experience at the airport can influence travel plans for future visits to a destination. Meanwhile, Hong et al. (2020) found that airport service quality is significantly related to airport reuse and destination revisits. According to Wattanacharoensil et al. (2017), an airport is a representative of a destination and exhibits the positive characteristics of such a place. Prentice and Kadan (2019) found that overall airport service quality is significantly related to airport reuse and destination revisit. Understanding this influence is important, especially when traveller perceptions of the airport is claimed to be an initial indicator of the destination/city's 'quality' or attractiveness (De Nicola et al., 2013). The notion that the airport image incorporates the destination attributes within it, was also found by Nghiem-Phu and Suter (2018), who suggested and confirmed that an airport has an active role in the creation of a visitor's first and last impressions of its host city.

The aforementioned studies imply that there is an association between a destination/city and the nearby airport, and suggest that air travellers can perceive the image of a destination based on their experience of the airport attributes. The more positive perceptions that air travellers acquire concerning the airport's sense of place and image, the more favourable the image they may perceive about the destination. Thus, the research investigates the influence of sense of place and holistic airport image, which are derived from the perceived cognitive and affective images, towards a destination image. Building upon the theoretical foundation of the airport literature, the following hypotheses are postulated:

H4: Passenger perception of the airport's sense of place affects the destination's image positively.

H5: The airport image affects the destination image positively.

The conceptual model for this study, as well as the five hypotheses, are shown in Figure 1.

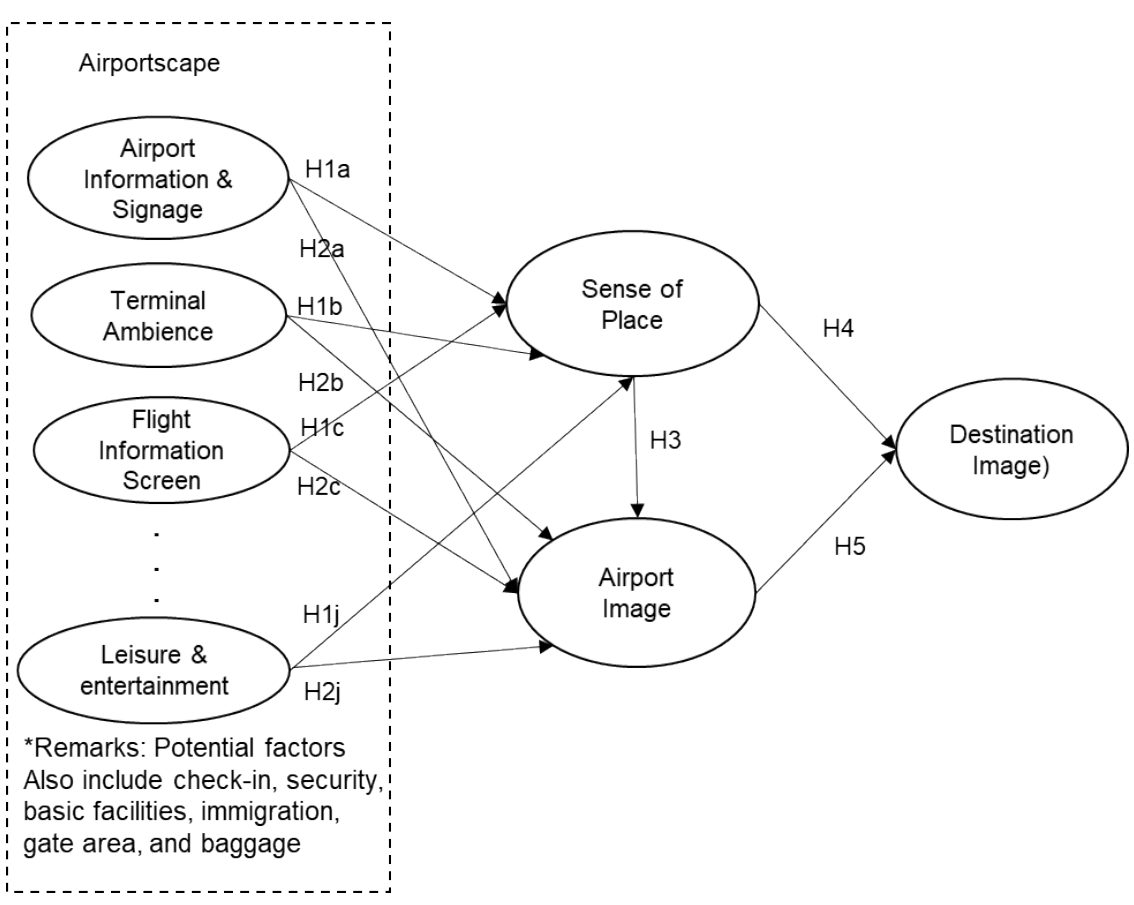

Figure 1: Proposed Conceptual Model 


\section{Methodology}

\section{Measurement development}

This study performed a scale development process as suggested by Hinkin (1995) to conduct scale validation for measuring the multidimensions of the airportscape. Qualitative techniques, namely, (1) an extensive review of the airport service quality and servicescape literature together with the related items from airport service quality by ASQ-ACI and (2) an expert panel review, were conducted to identify salient dimensions and refine the relevant attributes related to the physical environment at the airport.

The extensive review of the literature suggested 44 items from the airport's service environment, such as airport information/signage/layout, terminal ambience, flight information screens, check-in, security, basic facilities, immigration, gate area, baggage, and leisure/ entertainment, as listed in Table 1.

Table 1: Potential Dimensions and Related Literature for Airportscape

\begin{tabular}{|c|c|}
\hline Dimensions/ltems & Related Literature \\
\hline $\begin{array}{l}\text { Airport Information, Signage and Layout (Al) } \\
\text { Signage and wayfinding } \\
\text { Size of signage } \\
\text { Quantity of signage } \\
\text { Proper design of the airport's layout } \\
\text { Easy movement of the crowd within the airport's } \\
\text { layout }\end{array}$ & $\begin{array}{l}\text { Brida et al. (2016); } \\
\text { Prentice and Kadan (2019) }\end{array}$ \\
\hline Terminal Ambience (TA) & $\begin{array}{l}\text { Brida et al. (2016); } \\
\text { Prentice and Kadan (2019) }\end{array}$ \\
\hline $\begin{array}{l}\text { Lighting } \\
\text { Temperature } \\
\text { Appropriate announcement level } \\
\text { Desirable aroma } \\
\text { Clean facilities }\end{array}$ & \\
\hline Flight Information Screens (FI) & Brida et al. (2016); \\
\hline $\begin{array}{l}\text { Visible flight information screen } \\
\text { Updated information on screens } \\
\text { Suitable location of information screen } \\
\text { Availability of information screens }\end{array}$ & \\
\hline Check-in (CI) & $\begin{array}{l}\text { Bezerra and Gomes (2016); } \\
\text { Prentice and Kadan (2019) }\end{array}$ \\
\hline $\begin{array}{l}\text { Check-in staff } \\
\text { Efficient check-in process } \\
\text { Availability of baggage trolleys } \\
\text { Waiting time at check-in } \\
\text { Self-check-in kiosks }\end{array}$ & \\
\hline Security (SC) & $\begin{array}{l}\text { Bezerra and Gomes (2016); } \\
\text { Prentice and Kadan (2019) }\end{array}$ \\
\hline $\begin{array}{l}\text { Efficient security screening processes } \\
\text { Helpful security staff } \\
\text { Thorough security screening of passengers } \\
\text { Waiting time at security checkpoints }\end{array}$ & \\
\hline Basic Facilities (BF) & $\begin{array}{l}\text { Bezerra and Gomes (2016); } \\
\text { Prentice and Kadan (2019) }\end{array}$ \\
\hline
\end{tabular}


Clean washrooms/toilets

Availability of washrooms/toilets

Availability of WIFI and PCs

Wide range of restaurant products

Availability of banks/ATM/money exchange services

Availability of retail stores

Immigration (IM)

Waiting time in outbound immigration area

Waiting time in inbound immigration area

Waiting time in inbound baggage inspection area

\section{Gate Area (GA)}

Uncrowded departure gate

Provision of aerobridges from the terminal to the

aircraft

Comfortable seating in waiting gate area

Sufficient seating in gate area

Baggage (BG)

Satisfactory baggage processing facilities

Large circulation space for inbound baggage reclaim

Useful information display for inbound baggage

reclaim

Availability of baggage trolleys

\section{Leisure and Entertainment (LEN)}

Attractive interior decoration of the airport

Fashionable interior and exterior of the airport

Airport amenities

Interesting events and exhibitions

The 44 items identified from the literature review were then incorporated into questionnaire statements for a survey. Following the scale validation recommended by Hinkin (1995), the research used a content adequacy evaluation performed by a panel of experts. The experts were composed of three senior industry professionals from the airline industry and three university professors with research specialisms related to airline businesses. The panel was asked to assess the applicability of the attributes and provide recommendations for improving the questionnaire statements. The panel removed one item that was considered unclear and irrelevant to the study context, namely, 'information display for inbound baggage claim', and suggested adding four items, namely, 'communication of check-in staff', 'communication of security staff', 'reasonable price of food products at restaurants' and 'availability of bed-seating for transfer passengers'. As a result, 47 statements were contained in the survey questionnaire. The measures of airport image, destination image and sense of place were adopted from the scale and concepts proposed by Park and Park (2018), Wattanacharoensil et al. (2017) and Stedman (2003). Each item was assessed with a 7-point Likert-type scale ranging from $1=$ strongly disagree to $7=$ strongly agree .

\section{Data collection}

In consideration of the aims of this study, the data collection process required potential respondents in Thailand to complete a questionnaire regarding their recent experiences at an international airport in the past 12 months. An online survey platform was designed to obtain the data. Respondents were selected using a screening question ('I have visited an international airport as a passenger recently (in the past 12 months)'). Only those who answered 'Yes' were requested to participate in the survey. The respondents were also asked to answer a few questions regarding their recent experiences at the airport (e.g., indicating one international airport that they had visited within six months and indicating the airport that 
was still fresh in their memory). According to Belli (1998), these questions could prompt memory cues, which could assist respondents in recalling experiences from their life calendar.

Online questionnaires were disseminated via a link to networks of the researchers from February 2020 to March 2020 as travel restrictions were put into effect as a result of the COVID-19 pandemic, making it infeasible to administer the survey results at the airports. Moreover, given that the population of airport passengers over the past 12 months was difficult to obtain, this study adopted convenience and snowball sampling methods to detect the target respondents. Respondents were required to pass the link of the questionnaire to other potential respondents who might have frequently travelled. Consequently, 1189 questionnaires were obtained from the Thai respondents for the statistical analysis. The demographic information in Table 2 displays the characteristics of the air travellers in the survey.

Table 2: Demographic Characteristics of the Sample $(n=1189)$

\begin{tabular}{l|l|l|l}
\hline Profile Category & & Frequency & Percentage \\
\hline Gender & Male & 475 & 40.0 \\
& Female & 714 & 60.0 \\
\hline Age (years) & $18-20$ & 129 & 10.8 \\
& $21-30$ & 783 & 65.9 \\
& $31-40$ & 116 & 9.8 \\
& $41-50$ & 87 & 7.3 \\
& 51 or above & 74 & 6.2 \\
\hline Education & High school & 93 & 7.8 \\
& Associate degree & 86 & 7.2 \\
\hline Locations of visited & Undergraduate degree & 874 & 73.5 \\
airport & Postgraduate or above & 136 & 11.4 \\
\hline Period of last visit & Within Thailand & 879 & 73.9 \\
& Outside Thailand & 310 & 26.1 \\
\hline & Past 3 months & 525 & 44.2 \\
& Past 6 months & 287 & 24.1 \\
\hline
\end{tabular}

The demographic profiles of the sample showed that the gender ratio was comparable, with $60 \%$ female and $40 \%$ male respondents. The age group of 21-30 years was the largest group of respondents with $65.9 \%$, followed by the age groups 18-20 (10.8\%), 31-40 (9.8\%), 41-50 $(7.3 \%)$ and 51 or above $(6.2 \%)$. The majority of the respondents had attained undergraduate degrees $(73.5 \%)$, followed by those with postgraduate degrees $(11.4 \%)$. For the locations of visited airport, $73.9 \%$ were international airports located in Thailand (e.g., Suvarnabhumi Airport (BKK), Don Mueang International Airport (DMK), Phuket International Airport (HKT), Chiang Mai International Airport (CNX), Mae Fah Luang-Chiang Rai International Airport (CEI), and Hat Yai International Airport (HDY)), whilst $26.1 \%$ were airports situated in other countries, such as Japan, Korea, China, USA, Australia, and UK. Most respondents visited an international airport in the past 3 months $(44.2 \%)$, followed by those in the past 12 months $(31.7 \%)$ and those in the past 6 months $(24.1 \%)$.

\section{Findings}

\section{Testing of the measurement and structural models}

Before analysing the structural relationships amongst the examined variables, confirmatory factor analysis (CFA) was conducted to verify the proposed measurement model (Anderson and Gerbing, 1988). CFA was performed to obtain the validity of a 10-factor structure of the airportscape (i.e., airport information/signage/layout, terminal ambience, flight information 
screen, check-in, security, basic facilities, immigration, gate area, baggage, leisure/ entertainment) together with other studied variables (i.e., sense of place, airport image and destination image), as shown in Table 3. Goodness-of-fit measures, including chi-square ( $x 2)$ $=5785.286$, degree of freedom $(\mathrm{df})=1574$, root mean square error of approximation (RMSEA) $=0.047$, comparative fit index $(\mathrm{CFI})=0.94$ and non-normed fit index $(\mathrm{NNFI})=0.93$, indicated that the data theoretically supported the research framework. The validity assessment results also exhibited no convergent and discriminant validity issues. Therefore, the average variance extracted (AVE) for each factor was greater than 0.5 and higher than the squared correlation values under the studied constructs (Table 4). Composite reliability (CR) values of all constructs were also greater than the threshold value of 0.7 , which suggested adequate reliability (Bagozzi and Yi, 1988).

Table 3: Results of the CFA (Measurement Model)

\begin{tabular}{|c|c|c|}
\hline Factor & $\begin{array}{l}\text { Factor } \\
\text { Loading }\end{array}$ & t-value \\
\hline \multicolumn{3}{|l|}{ Airport Information, Signage and Layout (AI) } \\
\hline $\begin{array}{l}\text { 1. The airport's signage and wayfinding clearly direct passengers to the airport's } \\
\text { services/facilities. }\end{array}$ & 0.82 & 29.68 \\
\hline 2. The size of signage is appropriate. & 0.81 & 29.48 \\
\hline 3. The quantity of signage is sufficient. & 0.82 & 30.02 \\
\hline 4. The airport's layout is properly designed to cater for passenger special needs. & 0.77 & N/A \\
\hline $\begin{array}{l}\text { 5. The airport's physical layout avoids crowding and enables easy movement of } \\
\text { passengers. }\end{array}$ & 0.75 & 27.02 \\
\hline \multicolumn{3}{|l|}{ Terminal Ambience (TA) } \\
\hline 1. The lighting at the airport gives a pleasant feeling. & 0.77 & 28.16 \\
\hline 2. The temperature at the airport is comfortable. & 0.76 & 27.74 \\
\hline 3. The announcement levels at the airport are appropriate. & 0.69 & 24.72 \\
\hline 4. The aroma at the airport is fitting and desirable. & 0.77 & $\mathrm{~N} / \mathrm{A}$ \\
\hline 5. The airport maintains clean facilities. & 0.83 & 30.63 \\
\hline \multicolumn{3}{|l|}{ Flight Information Screens (FI) } \\
\hline 1. The screens are available and appropriately presented for passengers. & 0.88 & 41.05 \\
\hline 2. The information screens are clearly visible. & 0.80 & 39.66 \\
\hline 3. Information on the screens is always updated. & 0.82 & 36.54 \\
\hline 4. The location of information screens is suitable. & 0.75 & $\mathrm{~N} / \mathrm{A}$ \\
\hline \multicolumn{3}{|l|}{ Check-in (Cl) } \\
\hline 1. Check-in staff members are friendly, courteous and helpful. & 0.78 & 27.48 \\
\hline 2. Check-in staff communicate clear and appropriate messages. & 0.80 & 28.29 \\
\hline 3. The check-in process is efficient. & 0.72 & 29.17 \\
\hline 4. Baggage trolleys are available for passengers. & 0.75 & $\mathrm{~N} / \mathrm{A}$ \\
\hline 5. Waiting time at check-in is acceptable. & 0.81 & 28.46 \\
\hline 6. Self-check-in kiosks are appropriately designed and easy to use. & 0.73 & 25.54 \\
\hline \multicolumn{3}{|l|}{ Security (SC) } \\
\hline 1. I feel safe and secure during the security screening processes. & 0.84 & 35.45 \\
\hline 2. Security staff members are friendly, courteous and helpful. & 0.86 & 36.78 \\
\hline 3. Security staff communicate clear and appropriate messages. & 0.85 & 36.47 \\
\hline 4. Security screening for passengers and personal belongings is thorough. & 0.83 & $\mathrm{~N} / \mathrm{A}$ \\
\hline 5. Waiting time at security checkpoints is acceptable. & 0.83 & 35.01 \\
\hline \multicolumn{3}{|l|}{ Basic Facilities (BF) } \\
\hline 1. Washrooms/toilets are clean. & 0.78 & 28.29 \\
\hline 2. Washrooms/toilets are widely available for passengers. & 0.80 & 29.11 \\
\hline 3. WIFI and PCs are available for passengers. & 0.74 & 26.58 \\
\hline 4. Restaurants offer a wide range of products. & 0.76 & $\mathrm{~N} / \mathrm{A}$ \\
\hline
\end{tabular}




\begin{tabular}{|c|c|c|}
\hline 5. Restaurants offer products with reasonable prices. & 066 & 2327 \\
\hline $\begin{array}{l}\text { 6. Banks/ATM/money exchange services are available to cater for passenger } \\
\text { needs. }\end{array}$ & 0.71 & 25.30 \\
\hline $\begin{array}{l}\text { 7. Retail stores are available to cater for passenger needs. } \\
\text { Immigration (IM) }\end{array}$ & 0.75 & 26.99 \\
\hline 1. Waiting time in the outbound immigration area is acceptable. & 0.85 & 33.89 \\
\hline 2. Waiting time in the inbound immigration area is acceptable. & 0.85 & 33.83 \\
\hline 3. Waiting time at the inbound baggage belt area is acceptable. & 0.81 & $\mathrm{~N} / \mathrm{A}$ \\
\hline Gate Area (GA) & & \\
\hline 1. The departure hall is not crowded. & 0.82 & 35.53 \\
\hline $\begin{array}{l}\text { 2. The airport provides aerobridges in good condition that eases access from the } \\
\text { terminal to the aircraft. }\end{array}$ & 0.81 & 34.78 \\
\hline 3. The airport provides comfortable and spacious seating in the waiting gate. & 0.86 & 38.09 \\
\hline 4. The airport provides sufficient seating in the gate area. & 0.84 & $\mathrm{~N} / \mathrm{A}$ \\
\hline $\begin{array}{l}\text { 5. The airport provides sufficient bed-seating for transfer passengers. } \\
\text { Baggage (BG) }\end{array}$ & 0.80 & 33.88 \\
\hline 1. The baggage processing facilities are of good quality. & 0.85 & 30.86 \\
\hline 2. The circulation space for inbound baggage reclaim is large and pleasant. & 0.85 & 30.57 \\
\hline 3. The baggage trolleys are easy to find. & 0.76 & N/A \\
\hline Leisure and Entertainment (LEN) & & \\
\hline 1. The interior decoration of the airport is attractive. & 0.86 & 35.50 \\
\hline 2. The interior and exterior of the airport are up to date. & 0.88 & 36.67 \\
\hline 3. Use of the airport amenities is enjoyable. & 0.81 & $\mathrm{~N} / \mathrm{A}$ \\
\hline $\begin{array}{l}\text { 4. Events and exhibitions featured by the airport are interesting. } \\
\text { Airport Image (IMG) }\end{array}$ & 0.81 & 32.48 \\
\hline 1. I have a favourable image of the airport. & 0.88 & 43.60 \\
\hline 2. The atmosphere of the airport is excellent. & 0.89 & 45.25 \\
\hline 3. The airport provides its passengers with a sense of friendliness. & 0.88 & $\mathrm{~N} / \mathrm{A}$ \\
\hline 4. The airport provides its passengers with a sense of confidence. & 0.89 & 45.80 \\
\hline 5. The overall image of the airport is satisfactory. & 0.89 & 45.80 \\
\hline Sense of Place (SP) & & \\
\hline 1. The airport provides its passengers with a clear sense of place identity. & 0.85 & 41.72 \\
\hline $\begin{array}{l}\text { 2. Events and exhibitions provided by the airport reflect the unique culture of the } \\
\text { place and destination. }\end{array}$ & 0.84 & 40.18 \\
\hline 3. I feel a personal connection and attachment to the airport. & 0.89 & $N / A$ \\
\hline $\begin{array}{l}\text { 4. The airport is more than just an airport, and it makes travel more meaningful. } \\
\text { Destination Image (DMG) }\end{array}$ & 0.89 & 45.15 \\
\hline 1. The airport satisfactorily represents the image of the destination. & 0.91 & 47.02 \\
\hline $\begin{array}{l}\text { 2. The airport can provide the sense of the destination even when I do not have } \\
\text { a chance to visit the city itself. }\end{array}$ & 0.89 & $\mathrm{~N} / \mathrm{A}$ \\
\hline 3. The airport is representative of a destination. & 0.90 & 46.61 \\
\hline
\end{tabular}

Note: All factor loadings are significant at $p<0.000$. Parameters are fixed at 1.0 for maximum likelihood estimation. Thus, $t-v a l u e s$ are not obtained $(N / A)$ for parameters fixed at 1.0 for identification purposes. 
Table 4: Correlations (Squared Correlations), CR, AVE, Mean and Standard Deviation (SD)

\begin{tabular}{|c|c|c|c|c|c|c|c|c|c|c|c|c|c|}
\hline & Al & TA & FI & $\mathrm{Cl}$ & SC & BF & IM & GA & BG & LEN & IMG & SP & DMG \\
\hline Al & 1 & & & & & & & & & & & & \\
\hline TA & $.75(.57$ & 1 & & & & & & & & & & & \\
\hline FI & $.71(.51)$ & $.73(.54)$ & 1 & & & & & & & & & & \\
\hline $\mathrm{Cl}$ & $.68(.46)$ & $.71(.50)$ & $.76(.57)$ & 1 & & & & & & & & & \\
\hline SC & $.68(.46)$ & $.74(.54)$ & $.71(.50)$ & $.81(.66)$ & 1 & & & & & & & & \\
\hline BF & $.70(.49)$ & $.75(.56)$ & $.72(.51)$ & $.74(.55)$ & $.77(.60)$ & 1 & & & & & & & \\
\hline IM & $.61(.38)$ & $.66(.66)$ & $.62(.39)$ & $.69(.48)$ & $.73(.54)$ & $.79(.62)$ & 1 & & & & & & \\
\hline GA & $.69(.47)$ & $.73(.53)$ & $.69(.48)$ & $.72(.52)$ & $.77(.59)$ & $.82(.66)$ & $.80(.63)$ & 1 & & & & & \\
\hline BG & $.66(.44)$ & $.69(.47)$ & $.69(.48)$ & $.72(.51)$ & $.74(.55)$ & $.76(.57)$ & $.72(.52)$ & $.81(.65)$ & 1 & & & & \\
\hline LEN & $.68(.46)$ & $.70(.48)$ & $.64(.41)$ & $.65(.43)$ & $.69(.48)$ & $.77(.60)$ & $.69(.47)$ & $.79(.62)$ & $.74(.55)$ & 1 & & & \\
\hline IMG & $.69(.49)$ & $.73(.53)$ & $.67(.45)$ & $.69(.48)$ & $.74(.55)$ & $.76(.57)$ & $.69(.48)$ & $.79(.62)$ & $.74(.55)$ & $.82(.67)$ & 1 & & \\
\hline SP & $.65(.43)$ & $.66(.43)$ & $.58(.34)$ & $.61(.38)$ & $.65(.43)$ & $.72(.52)$ & $.64(.41)$ & $.70(.49)$ & $.65(.43)$ & $.79(.62)$ & $.81(.66)$ & 1 & \\
\hline DMG & $.63(.40)$ & $.62(.38)$ & $.57(.32)$ & $.60(.36)$ & $.64(.41)$ & $0.68(.47)$ & $.62(.39)$ & $.68(.47)$ & $.65(.43)$ & $.76(.57)$ & $.79(.63)$ & $.88(.77)$ & 1 \\
\hline CR & .90 & .88 & .89 & .89 & .92 & .90 & .88 & .91 & .86 & .96 & .95 & .92 & .93 \\
\hline AVE & .63 & .59 & .66 & .59 & .71 & .55 & .70 & .68 & .77 & .71 & .79 & .75 & .81 \\
\hline MEAN & 5.24 & 5.16 & 5.41 & 5.36 & 5.29 & 5.06 & 5.03 & 5.14 & 5.28 & 4.94 & 5.29 & 5.10 & 5.16 \\
\hline SD & 1.09 & 1.13 & 1.15 & 1.07 & 1.15 & 1.16 & 1.28 & 1.20 & 1.14 & 1.31 & 1.21 & 1.24 & 1.29 \\
\hline
\end{tabular}


Structural equation modelling (SEM) was performed to explore which airportscape dimensions influence the air traveller's perceived sense of place, airport image and destination image, and to determine whether these variables are in line with the proposed direction in the research hypotheses (Figure 2). The measurement model resulting from the CFA served as a basis for the structural model. The goodness-of-fit indices for the multidimensional airportscape and the examined variables (i.e., sense of place, airport image and destination image) indicated that the structural model satisfactorily fitted the data $(X 2=5801.73, \mathrm{df}=1584$, RMSEA $=0.047$, $\mathrm{CFI}=0.94$ and NNFI =0.93). The resulting SEM model revealed that four airportscape dimensions, namely, airport information, signage and layout $(b=0.14, \mathrm{t}=3.17)$, basic facilities $(b=0.19, \mathrm{t}=2.20)$, leisure and entertainment $(b=0.72, \mathrm{t}=12.80)$ and flight information screens $(b=-0.12, t=-2.49)$, influenced the air traveller's perceived sense of place significantly. Thus, H1 was partially supported.

Considering the relationship between the various airportscape factors and airport image, five dimensions, namely, terminal ambience $(b=0.10, t=2.28)$, security $(b=0.15, \mathrm{t}=3.31)$, gate area $(b=0.23, t=3.58)$, leisure \& entertainment $(b=0.30, t=5.75)$ and basic facilities $(b=$ $-0.14, t=-1.97$ ) were found to influence the airport image significantly. Thus, $\mathrm{H} 2$ was partially supported. The SEM model also suggested the positive relationships amongst sense of place, airport image and destination image. Sense of place strongly predicted the perceived image variables identified in this study: destination image $(b=0.86, \mathrm{t}=21.73)$ and airport image $(b$ $=0.37, \mathrm{t}=10.29$ ). Accordingly, $\mathrm{H} 3$ and $\mathrm{H} 4$ were supported. In addition, the airport image significantly positively affected destination image $(b=0.10, t=2.81)$. Thus, $\mathrm{H} 5$ was supported. The airportscape construct was found to explain $76 \%$ and $86 \%$ of the variance with sense of place and airport image, respectively. Subsequently, sense of place and airport image strongly explained $90 \%$ of the variance in the destination image construct. 


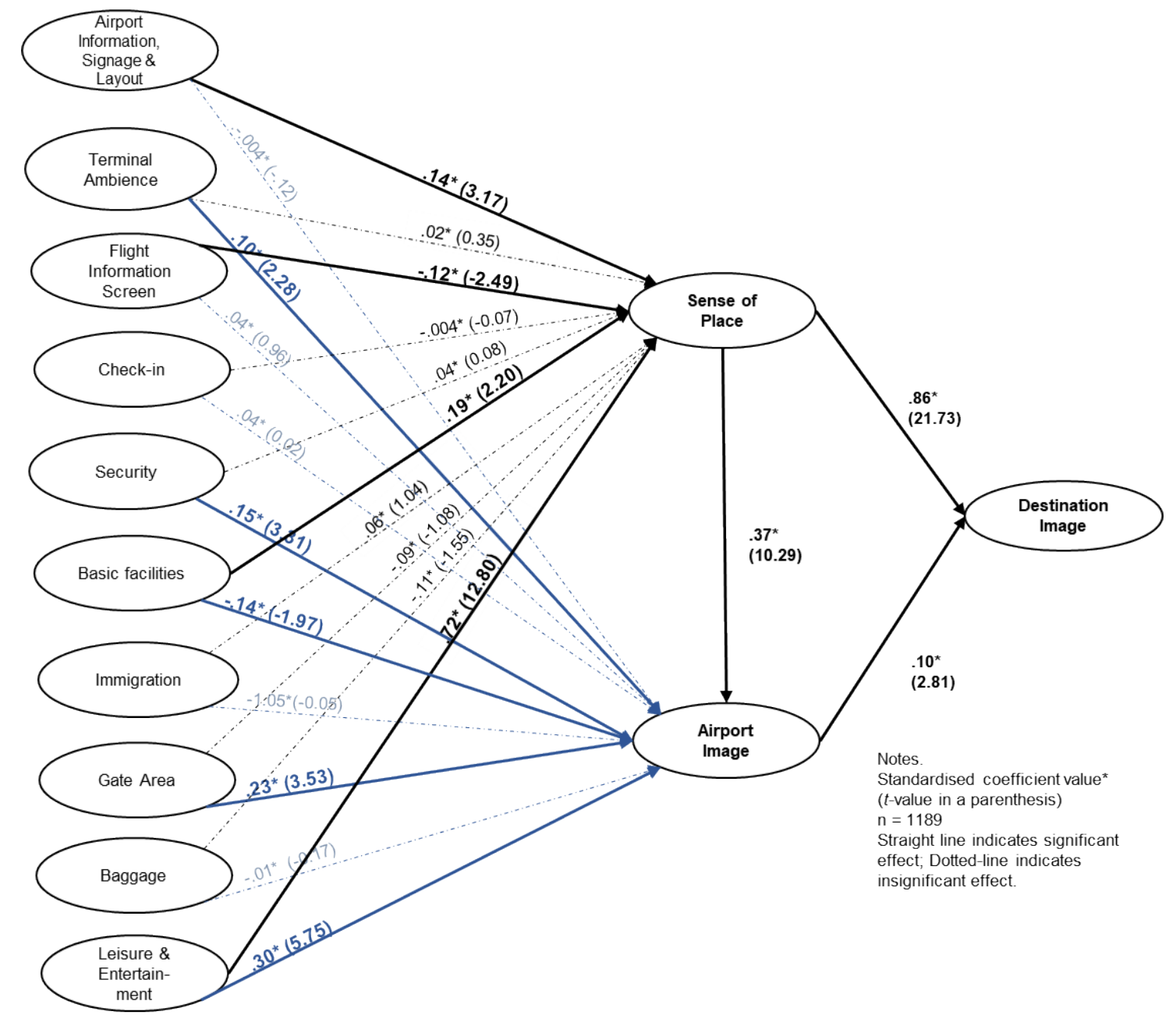

Figure 2: Results of the Conceptual Model

\section{Discussion and implications}

\section{Theoretical implications}

This study extends the previous literature by introducing the concept of the airportscape, which is a multidimensional construct that integrates the concepts of the airport physical environment (servicescape) and airport service quality dimensions into key functions and facilities in the airport terminal, covering the landside and airside areas. By incorporating the attributes from a thorough literature review of the servicescape, airport service quality, and related service quality items from the $A S Q-A C l$, together with additional items from the expert panel, the comprehensive airportscape construct was tested and developed. The research confirms the significance of the airportscape attributes and tests their nomological validity with sense of place, airport image and destination image. As a result, this research is amongst a very small number of studies that objectively connect the airport attributes to a destination. It unearths specific indicators which relate to how an airportscape can influence a positive airport's sense of place and airport image, and as a consequence, enhance the image of a destination. The concept of sense of place is found as an important mediator of the relationship between the airportscape dimensions and perceived image variables. Although previous studies have 
established the importance of these constructs (Moon et al., 2016; Nghiem-Phu and Suter, 2018; Stedman, 2003), an empirical examination of the structural relationships amongst the underlying concepts was not previously performed. The current research fills this gap by confirming the importance of the airportscape measurement and highlighting the mediating role of sense of place.

Based on the studied context of the Thai respondents, the findings reveal that certain elements from the airportscape attributes significantly influence the sense of place. The concept is thus important to promote airport identity and increase the opportunity to connect air travellers to a destination. This deduction supports the conceptual study by Wattanacharoensil et al. (2016). From the current study, the three attributes that promote a positive influence on the sense of place are 1) airport information, signage and layout; 2) basic airport facilities (washroom, restaurants, banks and retail stores); and 3) leisure and entertainment (interior and exhibitions). The findings indicate that the more positive perception the travellers have towards these elements, the higher the sense of place they perceive at the airport. This particular finding rings true especially as the majority of the respondents (approximately $74 \%$ ) visited the key international Thai airports where renovation attempts have been witnessed with the airport basic facilities (e.g., washroom, retail shops) to enhance the physical quality and the sense of Thailand as a destination. Bringing these findings into the broader context, the current study supports the previous work by Nghiêm-Phú and Suter (2018) on McCarran International Airport in Las Vegas, who found that the leisure, entertainment (slot machines) and basic facilities (airport Wi-fi) represented the destination at the airport (Las Vegas); and the study by Figueiredoa and Castro (2019) who addressed areas where sense of place could be created and perceived, comprising food and retail, architectural design and artwork.

By contrast, the study found that the flight information screens show a negative influence on sense of place. Therefore, the more air travellers focus on these components (regarding availability, location, visibility and up-to-date information on the screen), the less sense of place they will perceive. This finding can be generally explained by pinpointing the electronic and informative nature of the information screens that can lead air travellers towards tangible and objective evaluations. As sense of place generally involves the creation of a place's meaning and contains subjective evaluation and hedonic feelings, the results are comprehensible as the elements that influence the positive sense of place generally comprise items that can portray cultural or unique identity, and allow air travellers to envisage the destination's identity. However, such identity is hard to obtain from the flight information components, which are ubiquitously perceived to be technical and standardised in almost, if not, all airports. Therefore, this item shows a negative influence towards the sense of place which could be perceived more from the signage, facilities and leisure activities. This particular finding adds on to the previous literature as there are hardly any airport studies that mention the negative relationship between flight information screen and the sense of place creation.

When investigating the impact of the airportscape attributes on airport image, four items have shown a significantly positive influence in the current study, namely, 1) terminal ambience, 2) security, 3) gate area and 4) leisure and entertainment. Consideration of an airport image involves elements such as perceived atmosphere, confidence and satisfaction of air travellers; as a result, the four attributes have strong positive links to airport image. Despite being investigated entirely from a context of Thai respondents, this finding supports the previous study by Park and Ryu (2019), who found that ambience elements (e.g., scent and cleanliness) and seating comfort influence the affective satisfaction of air travellers and that 
positive affective satisfaction affects positive airport image. Thus, this current study confirms the importance of terminal ambience and gate area, together with elements of security and leisure and entertainment in the airport. However, an unexpected negative effect is found between basic facilities and the airport image. This result means that, the more air travellers experience the basic facilities at the airport, the lower the effect on their favourable perceptions of the airport image. This finding seems surprising but provides some noteworthy points, especially when considering that the respondents come from one single nationality. The finding may represent the specific context in the sense that by increasing these basic facilities (e.g.,WIFI, restaurants, bank ATMs, retail), the Thai respondents will develop less positive image perception of an airport. This could be explained by the fact that many international airports in the studies (mainly in Thailand) have incorporated a number of shops, food stores, and other facilities that may not fit well with the interior of the airport environment. For instance, evidence is found in commercial areas of some airports, e.g., in DMK or HKT, where they are filled with a variety of food shops and local products, which can make the overall airport atmosphere feel a little chaotic and less organised. Thus, considering that the airport image in this study covers the items relating to overall favourable perceptions, the respondents may not perceive these basic facilities to really represent the image of the airport.

In the previous airport literature, some key functions at the airport (i.e., check-in, immigration and baggage claim) are noted to be amongst the main points causing passenger stress and anxiety (Livingstone et al., 2012). By contrast, this present study does not observe any significant effects of the three functions on the sense of place and airport image. Their undetected influences on the sense of place can be explained considering the utilitarian nature of these functions. The impact of the check-in, immigration and baggage claim functions on the airport image may not be as critical or may not be perceived as key points as with earlier research. As most of these functions have now integrated the use of electronic services (e.g., self-check-in and e-immigration) to facilitate the functional processes, this may reduce the strong negative perception of air travellers towards the processes, particularly when the key respondents in this current study are those in the age group of less than 30 years old. Nevertheless, these functions may not create much higher satisfaction either, due to their statistical insignificance. Thus, the results do not show any significant explanatory power in relation to sense of place and airport image.

The findings also reveal that the sense of place strongly affects airport image, and this result supports the arguments of Nghiem-Phu and Suter (2018), who emphasised the importance of incorporating national identity into the airport image. The airport's sense of place and image influence the passenger perception of the destination image. However, the sense of place has a stronger positive influence on destination image. In other words, the stronger the airport promotes the sense of place within the three attributes in the airportscape construct, the more air travellers can perceive the image of a destination through their airport encounter lexperience.

The result of this study shows the strong interconnection between the sense of place and destination image. This finding complements the previous study by Wattanacharoensil et al. (2016) who found that sense of place and cultural identity were created - being highlighted by airport managers to enhance passenger airport experience. This current study further explains that passengers perceive the airport's sense of place through the three components found in the study (airport information, signage and layout; basic airport facilities and leisure and entertainment). Since these components strongly influence the sense of place, which as a 
consequence influence the perceived destination image, this study is amongst the pioneering work within the airport literature, by providing clarity as to where to envisage the destination image within the attributes of airportscape. This helps to strengthen the airport role as an ambassador for the destination.

\section{Managerial implications}

This study provides the following benefits to practitioners and airport management:

1) The verified multidimensional airportscape scales, comprising 47 attributes under ten dimensions, allows airport authorities and service providers to make strategic checklists and decisions in managing airport businesses and operations. The airportscape measurement can be exploited to assess whether the identified attributes fulfill a traveller's demands and preferences. A checklist can assist airport managers in highlighting the areas for improvement. If potential areas of concern are uncovered, more resources and effort can be devoted to these. For example, leisure and entertainment is deemed distinctive and critical for shaping experiences and for enhancing the sense of place and airport image of air travellers. So airport managers should constantly explore and provide such activities that are interesting to fulfill the expectations of air travellers. The provision of entertainment and leisure activities does not necessarily require a significant development of airport amenities/facilities. Instead, it can be offered based on the alluring and available resources of a destination where an airport is located. For example, cultural performances, local art exhibitions and historical showcases (Wattanacharoensil et al. 2017). The scale developed in this research can thus enable practitioners and authorities to design surveys that fully measure the performance and competitiveness of their airports.

2) The results help make the bridging role of the airport and the tourism industry more real and evident by highlighting areas that the airport can represent the destination's image within its terminal. The airport authorities can use a design concept that incorporates destination or national/cultural identities into the airport space through the three key airport functions, namely signage, basic facilities and leisure and entertainment. The last function (leisure and entertainment) has already been used at many international airports (e.g., ICN has cultural centres and HND has cultural market space) and represents the highest influence on the sense of place. However, the first two functions are still sparsely observed and should not be overlooked. The sense of place positively influences the destination image and airport image. Considering that the airport is perceived as the representative of the destination, and that air travellers observe the destination's characteristics in the airport terminal environment (Wattanacharoensil et al., 2017), it will thus be sensible that airport authorities liaise with DMO or tourism organisations in order to enhance the airport's sense of place, as the airport can provide first impression of the destination (Mohammadi et a., 2020). This will bring benefits to the airport and tourism industries.

3) Airport authorities can use the findings on the airport image to enhance the level of competitiveness and increase the positive perception of air travellers in relation to airport performance. Four key areas, namely airport ambience, security, gate area, and leisure and entertainment, which promote a positive airport image, should be particularly considered. The results show that leisure and entertainment also exhibit the highest influence on the airport image. This has a crucial influence on the airport image (and the sense of place), which reflects the current outlook that air travellers have of the airport, that is, moving the airport away from 
the utilitarian entity with a key functional purpose of travel to an entity that morphs into a hedonic and experiential outlet that plays a significant part in the tourism journey (Moon et al., 2016; Tovar and Martin-Cejas, 2009).

4). As a consequence of the COVID-19 pandemic, air travellers have increasing concern about health and safety whilst travelling (Abraham et al., 2020; Teeroovengadum et al., 2021). Given that advanced technology associated with health and safety can be implemented in several airportscape areas (e.g., immigration, security, airport information service, and check-in), airport management should employ information communication technologies (ICTs) to improve air traveller movements within these areas (Bogicevic et al. 2016). For example, technology that can track biometrics or realistic authentication can be utilized at the major international airports to facilitate travellers when checking in, boarding or processing through customs and immigration. Not only does the adoption of modern ICTs help airports to eliminate long lines at security or immigration, but it also strengthens confidence amongst travellers, as well as aviation workers regarding the health checks and safety processes at airports (Wen et al., 2020).

\section{Research limitations and recommendations}

Inevitably, this study has some limitations. The respondents are predominantly young and come from a single nationality, and the majority of the airports they chose to reflect their experience fall into one geographical/national context. Thus, the explanatory power of the model may be biased towards this particular airport context. Moreover, this study places importance on the service physical environment attributes to create the airportscape construct but did not include other servicescape elements, such as the social servicescape. This research follows ASQ-ACI related indicators, responding to the arguments and findings of Park and Ryu (2019), who did not find a significant influence of the social servicescape on the affective satisfaction and airport image of 283 respondents. However, additional studies should be conducted to confirm this point with a larger number of respondents. Future research is also encouraged to explore the relationship between an antecedent/consequence and the multidimensional airportscape. For example, a memorable experience construct relevant to the airport context can be used as a mediator. In addition, the potential variables (for instance gender, culture) which can affect how an individual perceives airport satisfaction and experience can be further investigated as a moderator. The prioritisation of the airport attributes that have been used in this research can be regarded as another study agenda. 


\section{References}

Abraham, V., Bremser, K., Carreno, M., Crowley-Cyr, L. and Moreno, M. (2020), "Exploring the consequences of COVID-19 on tourist behaviors: perceived travel risk, animosity and intentions to travel", Tourism Review, Vol. ahead-of-print No. ahead-of-print. https://doi.org/10.1108/TR-07-2020-0344.

Anderson, J. C. and Gerbing, D. W. (1988), "Structural equation modeling in practice: A review and recommended two-step approach", Psychological Bulletin, Vol.103 No.3, pp.411-423.

Ariffin, A. A. M. and Yahaya, M. F. (2013), "The relationship between airport image, national identity and passengers delight: A case study of the Malaysian low cost carrier terminal (LCCT)", Journal of Air Transport Management, Vol.31, pp.33-36.

Auge, M. (1995), Non-places: Introduction to an anthropology of supermodernity, London: Verso.

Bagozzi, R. P. and Yi, Y. (1988), "On the evaluation of structural equation models", Journal of the Academy of Marketing Science, Vol.16 No.1, pp.74-94.

Baker, J. (1986), "The role of the environment in marketing services: The consumer perspective". In J. Czepiel, C. Congram, \& J. Shanahan (Eds.), The services challenge: Integrating for competitive advantage (pp. 79-84), Chicago: American Marketing Association.

Belli, R.F. (1998), "The structure of autobiographical memory and the event history calendar: potential improvements in the quality of retrospective reports in surveys", Memory, Vol.6 No.4, pp.383-406.

Bezerra, G. C. L. and Gomes, C. (2016), "Measuring airport service quality: A multidimensional approach", Journal of Air Transport Management, Vol. 53, pp.85-93.

Bitner, M. J. (1992), "Servicescapes: The impact of physical surroundings on customers and employees", Journal of Marketing, Vol.56 No. 2, pp.57-71.

Bogicevic, V., Yang, W., Bilgihan, A. and Bujisic, M. (2013), "Airport service quality drivers of passenger satisfaction”, Tourism Review, Vol. 68 No.4, pp.3-18.

Bogicevic, V., Yang, W., Cobanoglu, C., Bilgihan, A. and Bujisic, M. (2016), "Traveler anxiety and enjoyment: The effect of airport environment on traveler's emotions", Journal of Air Transport Management, Vol.57, pp.122-129.

Brida, J. G., Moreno-Izquierdo, L., and Zapata-Aguirre, S. (2016), "Customer perception of service quality: The role of information and communication technologies (ICTs) at airport functional areas", Tourism Management Perspectives, Vol.20, pp. 209-216.

Chang, K.C. (2016), "Effect of servicescape on customer behavioral intentions: moderating roles of service climate and employee engagement, International Journal of Hospitality Management, Vol.53, pp. 116-128.

Dong, P., Siu, N.Y.M. (2013), "Servicescape elements, customer predispositions and service experience: the case of theme park visitors", Tourism Management, Vol.36, pp.541-551. 
Duval, D.T. (2020), "Transport and tourism: a perspective article", Tourism Review, Vol.75 No. 1 , pp. $91-94$

Elliot, S., Papadopoulos, N., and Kim, S. S. (2011), "An integrative model of place image: Exploring relationships between destination, product, and country images", Journal of Travel Research, Vol. 50 No.5, pp.520-534.

Fakfare, P. and Lee, J.-S. (2019), "Developing and validating a scale for multidimensional attributes of honeymoon tourism", Journal of Hospitality and Tourism Research, Vol.43 No.8, pp.1199-1224.

Figueiredo, T. and Castro, R. (2019), "Passengers perceptions of airport branding strategies: the case of Tom Jobim International Airport-RIOgaleão, Brazil", Journal of Air Transport Management, Vol. 74, pp.13-19.

Florido-Benítez, L. (2016), "The influence of demographic and situational characteristics in satisfaction and decision of tourism activities via mobile marketing", Cuadernos de Turismo, Vo. 38, pp.529-532.

Fodness, D. and Murray, B. (2007), "Passengers' expectations of airport service quality", Journal of Services Marketing, Vol.21, No.7, pp.492-506.

Fu, Y.K., Huang, W. and Liao, C.N, (2020), "The selection model for horizontal alliances between hotels and airlines: An integrated application of NGT, Fuzzy TOPSIS and MCGP methods", Tourism Review, Vol.75, No.4, pp.681-698.

Graham, A. (2019), "Airport management: a perspective article", Tourism Review, Vol.75, No.1, pp.102-108.

Hinkin, T. (1995), "A review of scale development practices in the study of organizations", Journal of Management, Vol. 21, pp.967-988.

Holbrook, M. B. and Hirschman, E. C. (1982), "The experiential aspects of consumption: Consumer fantasies, feelings, and fun", Journal of Consumer Research, Vol.9 No.2, pp.132-140.

Holland, J. (2017), "Sense of Place now a key part of the airport experience, says latest m1nd-set report", The Moodie Davitt Report. Retrieved from

https://www.moodiedavittreport.com/sense-of-place-now-a-key-part-of-the-airportexperience-says-latest-m1nd-set-report/

Hong, S. J., Choi, D. and Chae, J. (2020), "Exploring different airport users' service quality satisfaction between service providers and air travelers", Journal of Retailing and Consumer Services, Vol. 52, 101917.

Hyun, S. S. and Kang, J. (2014), "A better investment in luxury restaurants: Environmental or non-environmental cues?", International Journal of Hospitality Management, Vol.39, pp.57-70.

Incheon International Airport Corporation (2020), Korea Traditional Culture Experience Center (T1 East), Incheon International Airport. Retrieved from https://www.airport.kr/ap/en/svc/attractionDetail.do?TERMINAL_ID=T1\&SN=1975 
Jen, W., Lu, M. L., Hsieh, E. H., Wu, Y. H., and Chan, S. M. (2013), "Effects of airport servicescape on passengers' satisfaction: A hierarchical approach and ImportancePerformance analysis", Journal of the Eastern Asia Society for Transportation Studies, Vol.10, pp.2223-2234.

Jeon, S. and Kim, M. S. (2012), "The effect of the servicescape on customers' behavioral intentions in an international airport service environment”, Service Business, Vol.6 No.3, pp.279-295.

Kaduoka, C. (2019), Let's create sense of place, SITA. Retrieved from https://www.sita.aero/air-transport-it-review/articles/lets-create-a-sense-ofplace?Catld=10866

Kirk, P., Harrison, A., Popovic, V. and Kraal, B. (2014), "Deconstructing expected passenger experience in airports". In DRS2014 international conference of the design research society proceedings. Umea, Sweden.

Li, S. (2021), "Linking servicescape and customer engagement: An investigation in the hotel context”, International Journal of Hospitality Management, Vol.94, 102880.

Livingstone, A., Popovic, V., Kraal, B. J., and Kirk, P. J. (2012), "Understanding the airport passenger landside retail experience". In P. Israsena, J. Tangsantikul,\& D. Durling, (Eds.), DRS 2012 Bangkok Research: Uncertainty, Contradiction and Value. Bangkok: Department of Industrial Design, Faculty of Architechture, Chulalongkorn University.

Lloyd, J. (2003), "Airport technology, travel, and consumption", Space and Culture, Vol.6 No.2, pp.93-109.

MacKenzie, K. (2019, February 28), To Brand. To Act. The Team. Retrieved from https://www.theteam.co.uk/blog/to-brand-to-act-airport-branding/

Masjutina, S. (2017). Airport Branding. Creating a Sense of Place in Airports. The Place Brand Observer. Retrieved from https://placebrandobserver.com/how-to-create-sense-of-placeairports/

Ministry of Foreign Affairs of Japan (2020), Haneda airport: Gateway to Tokyo from the world. Web Japan. Retrieved from https://web-japan.org/trends/09_food/jfd110127.html

Mohammadi, F., Yazdani, H.R., Jami Pour, M. and Soltani, M. (2021), "Co-creation in tourism: a systematic mapping study", Tourism Review, Vol. 76 No. 2, pp. 305-343. https://doi.org/10.1108/TR-10-2019-0425

Moon, H., Yoon, H. J. and Han, H. (2016), "Role of airport physical environments in the satisfaction generation process: Mediating the impact of traveller emotion", Asia Pacific Journal of Tourism Research, Vol.21 No.2, pp.193-211.

Nghiêm-Phú, B. and Suter, J. R. (2018), "Airport image: An exploratory study of McCarran International Airport”, Journal of Air Transport Management, Vol.67, pp.72-84.

De Nicola, A., Gitto, S. and Mancuso, P. (2013), "Airport quality and productivity changes: A Malmquist index decomposition assessment", Transportation Research Part E: Logistics and Transportation Review, Vol.58, pp.67-75. 
Parasuraman, A., Zeithaml, V. A., and Berry, L. L. (1985), "A conceptual model of service quality and its implications for future research", Journal of marketing, Vol.49 No.4, pp.4150.

Park, K. and Park, J. W. (2018), "The effects of the servicescape of airport transfer amenities on the behavioral intentions of transfer passengers: A case study on Incheon International Airport", Journal of Air Transport Management, Vol.72, pp.68-76.

Park, J. W. and Ryu, Y. K. (2019), "Investigating the effects of airport servicescape on airport users' behavioral intentions: A case study of Incheon International Airport Terminal 2 (T2)", Sustainability, Vol.11 No.15, 4171.

Prentice, C. and Kadan, M. (2019), "The role of airport service quality in airport and destination choice", Journal of Retailing and Consumer Services, Vol.47, pp.40-48.

Relph, E. (1976), Place and placelessness, London: Pion.

Rosenbaum, M.S., and Massiah, C. (2011), "An expanded servicescape perspective”, Journal of Service Management, Vol.22 No.4, pp.471-490.

Rowley, J., and Slack, F. (1999), "The retail experience in airport departure lounges: reaching for timelessness and placelessness", International Marketing Review, Vol.16 No.4/5, pp.363-376.

Sarlay, S, \& Neuhofer, B (2020), "Sharing economy disrupting aviation: travelers' willingness to pay", Tourism Review, ahead-of-print.

Shamai, S. (1991), "Sense of place: An empirical measurement", Geoforum, Vol. 22 No. 3, pp. 347-358.

Stedman, R. C. (2003), "Is it really just a social construction?: The contribution of the physical environment to sense of place", Society \& Natural Resources, Vol.16 No.8, 671-685.

Teeroovengadum, V., Seetanah, B., Bindah, E., Pooloo, A. and Veerasawmy, I. (2021), "Minimising perceived travel risk in the aftermath of the COVID-19 pandemic to boost travel and tourism", Tourism Review, Vol. ahead-of-print No. ahead-of-print. https://doi.org/10.1108/TR-05-2020-0195

Tovar, B. and Martin-Cejas, R. R. (2009), "Are outsourcing and non-aeronautical revenues important drivers in the efficiency of Spanish airports?", Journal of Air Transport Management, Vol.15, pp.217-220.

Trischler, J. and Lohmann, G. (2018), "Monitoring quality of service at Australian airports: A critical analysis", Journal of Air Transport Management, Vol. 67, pp.63-71.

Tsai, W. H., Hsu, W. and Chou, W. C. (2011), "A gap analysis model for improving airport service quality", Total Quality Management \& Business Excellence, Vol.22 No.10, pp.1025-1040.

Wattanacharoensil, W., Schuckert, M. and Graham, A. (2016), "An airport experience framework from a tourism perspective", Transport Reviews, Vol.36 No.3, pp.318-340. 
Wattanacharoensil, W., Schuckert, M., Graham, A. and Dean, A. (2017), "An analysis of the airport experience from an air traveler perspective", Journal of Hospitality and Tourism Management, Vol. 32, pp.124-135.

Wen, J., Kozak, M., Yang, S. and Liu, F. (2020), "COVID-19: potential effects on Chinese citizens' lifestyle and travel”, Tourism Review, Vol. 76, pp.74-87.

Whang, H., Yong, S. and Ko, E. (2016), "Pop culture, destination images, and visit intentions: Theory and research on travel motivations of Chinese and Russian tourists", Journal of Business Research, Vol.69, pp.631-641. 